\title{
ANALISIS KEMAMPUAN SISWA DALAM MENULIS HURUF AL-QURAN PADA SISWA DI SD UMUM DAN BERBASIS ISLAM
}

\author{
Endang Solihah ${ }^{1}$, Salsabila Siti Nafisyah ${ }^{2}$, Wita Puspita Dewi ${ }^{3}$, Ani Nur Aeni ${ }^{4}$ \\ ${ }^{1234}$ Universitas Pendidikan Indonesia \\ e-mail: ${ }^{1}$ endangsolihah@upi.edu, ${ }^{2}$ salsabila.nafisyah@upi.edu, ${ }^{3}$ witapuspitadewi@upi.edu \\ 4aninuraeni@upi.edu
}

Diterima: 04 Juni 2021 I Direvisi: 11 Oktober 2021 I Disetujui: 01 November 2021 (C) 2021 Pendidikan Guru Madrasah Ibtidaiyah Fakultas Agama Islam Universitas Islam Malang

\begin{abstract}
Abstrak
Al-Qur'an adalah kitab suci dari agama islam yang merupakan agama mayoritas di Indonesia. Mempelajari Al-Qur'an merupakan suatu kewajiban yang Allah SWT perintahkan. Terdapat berbagai cara dalam mempelajari Al-Qur'an, salah satunya yaitu mempelajari bagaimana membaca dan menulis Al-Qur'an yang termasuk pada kurikulum pendidikan agama islam di sekolah dasar. Keterampilan membaca dan menulis Al-Qur'an merupakan satu kesatuan yang tidak dapat dipisahkan. Penelitian ini bertujuan untuk mengetahui bagaimana kemampuan siswa SD umum dan SD berbasis islam dalam menulis Al-Qur'an, dan untuk mengetahui perbedaan kemampuan menulis huruf Al-Qur'an antara siswa SD umum dengan siswa SD berbasis islam. Metode penelitian yaitu kuantitatif dengan pendekatan deskriptif. Untuk pengumpulan data hasil tes keterampilan menulis surat Al-Ikhlas diunggah partisipan melalui link google form. Partisipan berjumlah 34 orang siswa dari SD umum dan SD berbasis islam yang tersebar dari beberapa kabupaten/kota di Jawa Barat. Dari penelitian ini diperoleh hasil: 1) Kemampuan menulis Al-Qur'an siswa SD umum lebih unggul siswa SD berbasis islam, 2) Terdapat perbedaan kemampuan menulis Al-Qur'an antara siswa SD umum dengan siswa SD berbasis islam dan perbedaan tersebut terlihat dari perbedaan nilai ratarata terdapat selisih sebesar 8,80,3) Jenis sekolah tidak berpengaruh terhadap kemampuan menulis Al-Qur'an siswa, dan 4) Gender mempengaruhi kemampuan menulis Al-Qur'an karena terdapat perbedaan hasil dimana siswa perempuan lebih unggul daripada siswa laki-laki.
\end{abstract}

Kata kunci: kemampuan menulis, Al-Qur'an, sekolah dasar.

\begin{abstract}
Al-Qur'an is the holy book of Islam which is the majority of religion in Indonesia. Learning Al-Qur'an is an obligation that Allah SWT has commanded. There are various ways to learning Al-Qur'an, for example is learning how to read and write Al-Qur'an which is include in the Islamic religious education curriculum in elementary schools. This writing and reading skill of Al-Qur'an is the integrated that can't be separated. This research purpose is to determine the student ability of general elementary school and Islamic-based elementary school in writing the Al-Qur'an. The research method is using quantitative with a descriptive approach. To collect data, the Al-Ikhlas writing test result were uploaded in google form link. The participants were 34 students from general elementary school and Islamic-based schools spread from several districts/cities in West Java. From this research the result is: 1) The ability to write Al-Qur'an of general elementary school students is better than Islamic-based elementary school students. 2) there are ability differences of writing Al-Qur'an between general elementary school students and Islamic-based school students, the average value is 8,80,3) the school
\end{abstract}


type doesn't affect the ability of writing Al-Qur'an, and 4) Gender has affects to ability of writing AlQur'an because there are differences where female students are better than male students.

Key words: writing ability, Al-Qur'an, elementary school.

\section{PENDAHULUAN}

Agama Islam adalah agama yang dianut ratusan juta orang di seluruh dunia, termasuk Indonesia sebagai negara mayoritas beragama islam. Salah satu mukjizat terbesar bagi umat islam adalah Al-Qur'an. Kata Al-Qur'an berasal dari "Qa'arayaqra-u-qirā-atan wa Qur-ānan" yang artinya membaca (Aeni, 2017). Dapat didefinisikan bahwa Al-Qur'an yaitu firman Allah yang tidak ada tandingannya, AlQur'an diturunkan kepada Nabi Muhammad penutup para nabi dan rasul, dengan perantara Malaikat Jibril dan ditulis dalam bentuk mushaf-mushaf (Aeni, 2017).

Al-Qur'an adalah kitab yang diturunkan oleh Allah SWT kepada Rasulullah SAW, untuk disampaikan kepada umat manusia. Ada beberapa cara untuk berinteraksi dengan Al-Quran yaitu mengimani, mempelajari, menghafalkan, dan mentadabburi. Salah satunya kita dapat mempelajari Al-Qur'an yang meliputi membaca dan menulis Al-Qur'an yang sebagaimana Allah SWT perintahkan kepada Rasulullah SAW. "in addition, when they do not understand the contents of Al-Qur'an, they cannot practice and make Al-Qur'an as their life guidance" (Supriyadi, et al. 2019). Jika tidak dapat membaca Al-Qur'an maka tidak dapat mengerti isi AlQur'an dan menjadikan Al-Qur'an sebagai pedoman menjalani kehidupan.

Mengenalkan, mengajarkan, dan membimbing anak mempelajari Al-Qur'an sejak dini sangatlah penting karena Al-Qur'an merupakan pintu dari segala ilmu yang ada muka bumi terutama ilmu agama. Selain itu juga dapat menumbuhkan kepercayaan anak kepada Allah SWT dan Al-Qur'an itu sendiri sehingga seiring berjalan waktu anak akan memahami dan menemukan dengan sendirinya mengenai konsep mengimani Al-Qur'an. Pengenalan Al-Qur'an dimulai dari rumah, madrasah, dan sekolah sebagai lingkungan pendidikan formal. Menulis dan mengenali huruf adalah keterampilan pertama yang dikenalkan kepada siswa sebelum mereka memasuki pendidikan formal. Mempelajari Al-Qur'an pada dasarnya adalah proses memperkenalkan Al-Qur'an itu sendiri kepada siswa, dengan tujuan agar siswa dapat menulis Al-Qur'an dengan baik sesuai dengan aturan yang telah ditetapkan dalam ilmu tajwid. Di sekolah pembelajaran baca tulis Al-Qur'an merupakan bagian dari mata pelajaran PAI (Pendidikan Agama Islam) yang ada di semua jenjang pendidikan, mulai dari SD sampai perguruan tinggi. 
Budaya dalam mempelajari Al-Qur'an yang mana membaca dan menulis AlQur'an di kalangan siswa tingkat SD/sederajat dapat dikatakan masih jauh dari harapan, karena disebabkan oleh kurangnya semangat dan motivasi membaca yang akan berakibat juga pada lemahnya kemauan untuk menulis Al-Qur'an (Aminah 2019). Padahal membaca dan menulis Al-Qur'an merupakan dua keterampilan yang berkorelasi karena kadang ada siswa yang mampu membaca tapi tidak bisa menulis Al-Qur'an begitupun sebaliknya.

Berdasarkan pendapat Aminah (2019) dapat disimpulkan bahwa saat ini banyak siswa SD kehilangan minat dalam membaca dan menulis Al-Qur'an. Kehilangan minat dalam membaca dan menulis Al-Qur'an ini disebabkan oleh pengaruh lingkungan, proses modernisasi, dampak dari perkembangan teknologi yang sangat pesat, penggunaan alat-alat canggih, dan digitalisasi. Tidak dapat dipungkiri bahwa kebanyakan siswa SD bahkan mahasiswa lebih menyukai segala sesuatu yang berbasis teknologi dan internet dalam melakukan aktivitas belajar dan kegiatan sehari-hari.

Tidak heran jika saat ini banyak sekali siswa SD yang belum bisa bahkan buta dalam membaca dan menulis Al-Qur'an. Pada akhirnya akan menyebabkan perbedaan kemampuan membaca atau menulis Al-Qur'an antara siswa yang satu dengan yang lainnya. Dalam proses pembelajaran, perbedaan tersebut bisa juga dipengaruhi oleh bermacam-macam faktor. Dalam hal ini bisa ditentukan oleh guru pembimbing/guru kelas/guru PAI, cara pengajarannya, metode pembelajaram, kurikulum sekolah, intensitas pembelajaran, dan jenis sekolah.

Dalam penelitian yang dilakukan oleh Wulandari (2018) didapatkan hasil penelitian dimana dapat diketahui bahwa: "1) Penerapan pembelajaran Practice Rehearsal Pairs selama proses pembelajaran Al-Qur'an Hadis pada materi menulis Al-Qur'an surat al-maun, al-kafirun, dan at-takasur telah berlangsung dengan baik sesuai dengan langkah-langkah yang direncanakan. Dapat dilihat dari nilai akivitas siswa siklus I sebesar 75,12 dan naik pada siklus II menjadi 86,76. 2) Peningkatan keterampilan pada kemampuan belajar yang memuaskan karena dari pra siklus yang hanya mendapat nilai rata-rata 74,53 dengan presentase ketuntasan yang mencapai $40 \%$ hasil ini dapat dilihat meningkat dengan diadakannya penelitian dengan nilai rata-rata yang diperoleh 75,12 dengan presentase ketuntasan mencapai $56,7 \%$ pada siklus I dan meningkat pada siklus II diperoleh nilai ratarata siswa 90,02 dengan prosentase ketuntasan mencapai 86,7\%". Pada penelitian yang akan dilakukan penulis merupakan jenis penelitian kualitatif dan fokus penelitiannya adalah menganalisis kemampuan menulis Al-Qur'an siswa SD umum dan berbasis Islam, kemudian membandingkannya lebih unggul SD yang mana. 


\section{METODE}

Metode penelitian adalah cara-cara yang sifatnya ilmiah untuk mendapatkan data dengan tujuan dan kegunaan tertentu (Sugiyono 2019). Cara ilmiah yang dimaksud yaitu kegiatan penelitian harus berdasarkan ciri-ciri keilmuan yang meliputi rasional, empiris, dan sistematis. Adapun metode yang digunakan pada penelitian ini adalah metode kuantitatif dengan pendekatan deskriptif. Penelitian ini berlokasi di provinsi Jawa Barat. Partisipan pada penelitian ini adalah siswa kelas IV dari berbagai SD umum dan SD berbasis Islam yang berasal dari berbagai Kabupaten dan Kota di Jawa Barat. Penelitian ini melibat 34 orang partisipan dengan karakteristik sebagai berikut:
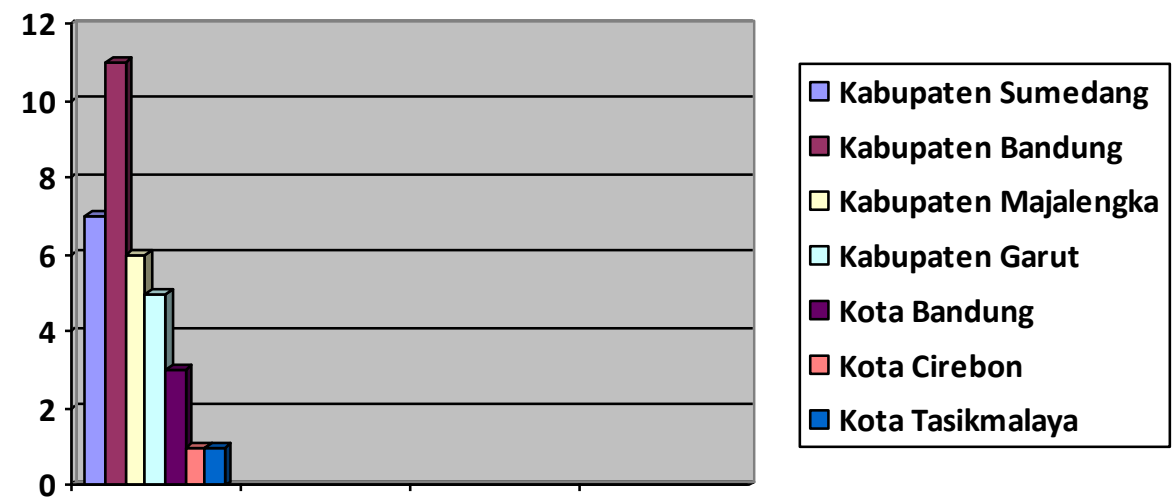

Grafik 1. Domisili Partisipasin
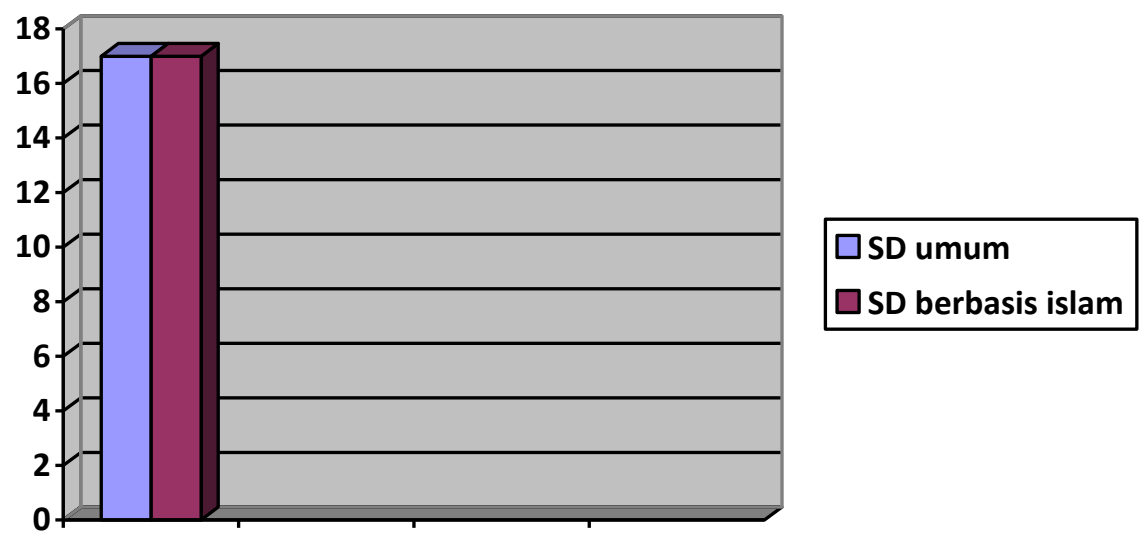

Grafik 2. Jenis Sekolah Partisipasin 


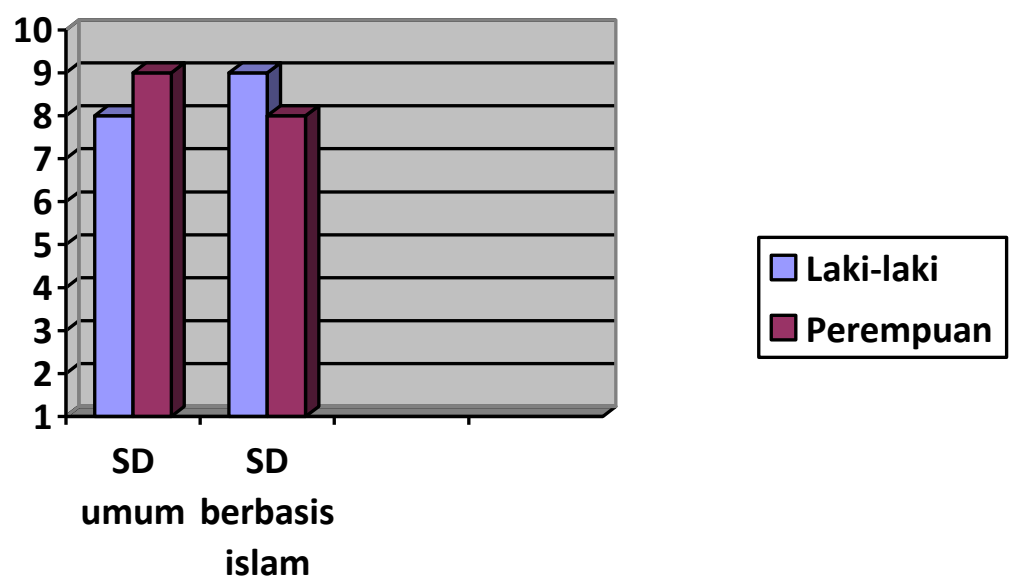

\section{Grafik 3. Gender Partisipasin}

Pada penelitian ini pengumpulan data diambil dengan cara melakukan tes keterampilan yang kemudian hasilnya dikumpulkan melalui Google Form. Kemudian teknik pengolahan data terhadap hasil tes keterampilan adalah dengancara mengumpulkan, menilai, mempersentasekan, dan menyimpulkan/menginterpretasikan. Pengambilan data pada penelitian ini diambil dengan menggunakan instrumen penilaian sebagai berikut:

\begin{tabular}{|c|c|c|c|c|}
\hline No & Aspek & Kriteria & Skor & Keterangan \\
\hline \multirow[t]{8}{*}{1} & \multirow[t]{8}{*}{ Tulisan } & \multirow[t]{4}{*}{$\begin{array}{l}\text { Penulisan } \\
\text { huruf hijaiyah }\end{array}$} & 4 & $\begin{array}{l}\text { Penulisan huruf (terutama saat } \\
\text { menyambungkan huruf hijaiyah) benar, } \\
\text { sesuai ketentuan, dan tidak tertukar } \\
\text { huruf. }\end{array}$ \\
\hline & & & 3 & $\begin{array}{lrll}\text { Ada } 5 & \text { kesalahan } & \text { penulisan } & \text { huruf } \\
\text { hijaiyah } & & \\
\end{array}$ \\
\hline & & & 2 & Ada 10 penulisan huruf hijaiyah \\
\hline & & & 1 & $\begin{array}{l}\text { Ada lebih dari } 10 \text { penulisan huruf } \\
\text { hijaiyah }\end{array}$ \\
\hline & & \multirow[t]{4}{*}{$\begin{array}{l}\text { Ketepatan } \\
\text { tanda baca }\end{array}$} & 4 & $\begin{array}{l}\text { Semua tanda baca sudah benar dan } \\
\text { sesuai }\end{array}$ \\
\hline & & & 3 & Tanda baca salah 5 \\
\hline & & & 2 & Tanda baca salah 10 \\
\hline & & & 1 & Tanda baca salah lebih dari 10 \\
\hline \multirow[t]{4}{*}{2} & \multirow[t]{4}{*}{ Kerapihan } & \multirow{4}{*}{$\begin{array}{l}\text { Kerapihan } \\
\text { tulisan }\end{array}$} & 4 & Tulisan sangat rapih dan mudah dibaca \\
\hline & & & 3 & Tulisan rapih dan mudah dibaca \\
\hline & & & 2 & $\begin{array}{l}\text { Tulisan agak rapih dan masih bisa } \\
\text { dibaca }\end{array}$ \\
\hline & & & 1 & Tulisan tidak rapih dan tidak bisa dibaca \\
\hline
\end{tabular}

Tabel 1. Instrumen Penilaian 
Endang Solihah, Salsabila Siti Nafisyah, Wita Puspita Dewi, Ani Nur Aeni

Untuk menghitung nilai hasil tes digunakan rumus sebagai berikut:

Nilai $=\underline{\text { Skor perolehan }}$ X 100

Skor maksimal

Setelah data terkumpul dan dinilai, lalu hasilnya ditafsirkan ke dalam kategori di bawah ini:

\begin{tabular}{|l|l|}
\hline Rentang Nilai & $\begin{array}{c}\text { Kategori Kriteria } \\
\text { Kemampuan Menulis } \\
\text { Huruf Al-Qur'an }\end{array}$ \\
\hline $81-100$ & Sangat baik \\
\hline $61-80$ & Baik \\
\hline $41-60$ & Cukup \\
\hline $21-40$ & Kurang \\
\hline$<20$ & Perlu bimbingan \\
\hline
\end{tabular}

Tabel 2. Kategori Kriteria Penilaian

HASIL DAN PEMBAHASAN

1. Kemampuan menulis Al-Qur'an surat Al-Ikhlas siswa SD umum dan SD berbasis islam

\begin{tabular}{ccrc}
\hline Siswa Ke- & Gender & \multicolumn{1}{c}{ Nilai } & Kriteria Kemampuan Menulis Al-Quran \\
\hline $\mathbf{1}$ & $\mathrm{L}$ & 66,67 & Baik \\
\hline $\mathbf{2}$ & $\mathrm{P}$ & 100,00 & Sangat baik \\
\hline $\mathbf{4}$ & $\mathrm{L}$ & 91,67 & Sangat baik \\
\hline $\mathbf{5}$ & $\mathrm{L}$ & 100,00 & Sangat baik \\
\hline $\mathbf{6}$ & $\mathrm{P}$ & 91,67 & Sangat baik \\
\hline $\mathbf{7}$ & $\mathrm{P}$ & 91,67 & Sangat baik \\
\hline $\mathbf{8}$ & $\mathrm{L}$ & 91,67 & Sangat baik \\
\hline $\mathbf{9}$ & $\mathrm{P}$ & 83,33 & Sangat baik \\
\hline $\mathbf{1 0}$ & $\mathrm{P}$ & 100,00 & Sangat baik \\
\hline $\mathbf{1 1}$ & $\mathrm{P}$ & 100,00 & Sangat baik \\
\hline $\mathbf{1 2}$ & $\mathrm{L}$ & 75,00 & Baik \\
\hline $\mathbf{1 3}$ & $\mathrm{L}$ & 58,33 & Cukup \\
\hline $\mathbf{1 4}$ & P & 83,33 & Sangat baik \\
\hline $\mathbf{1 5}$ & P & 100,00 & Sangat baik \\
\hline $\mathbf{1 6}$ & L & 100,00 & Sangat baik \\
\hline $\mathbf{1 7}$ & L & 100,00 & Sangat baik \\
\hline Rata-Rata Nilai & P & 100,00 & Sangat baik \\
\hline
\end{tabular}

Tabel 3. Data Hasil Penilaian Menulis Al-Quran Siswa SD Umum 
Endang Solihah, Salsabila Siti Nafisyah, Wita Puspita Dewi, Ani Nur Aeni

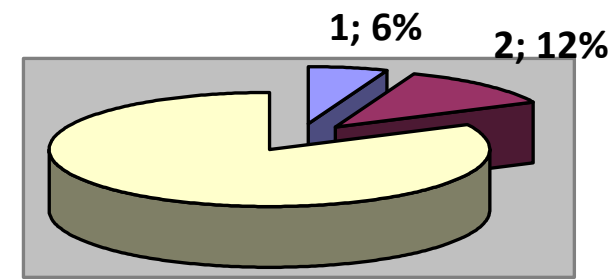

$\square$ Cukup

Baik

Sangat Baik

$14 ; 82 \%$

Diagram 1. Kriteria Kemampuan Menulis Al-Quran Siswa SD Umum

\begin{tabular}{ccrc}
\hline Siswa Ke- & Gender & \multicolumn{1}{c}{ Nilai } & Kriteria Kemampuan Menulis Al-Quran \\
\hline $\mathbf{1}$ & $\mathrm{P}$ & 100,00 & Sangat baik \\
\hline $\mathbf{2}$ & $\mathrm{L}$ & 83,33 & Sangat baik \\
\hline $\mathbf{4}$ & $\mathrm{L}$ & 66,67 & Baik \\
\hline $\mathbf{5}$ & $\mathrm{L}$ & 66,67 & Baik \\
\hline $\mathbf{6}$ & $\mathrm{L}$ & 100,00 & Sangat baik \\
\hline $\mathbf{7}$ & $\mathrm{P}$ & 66,67 & Baik \\
\hline $\mathbf{8}$ & $\mathrm{L}$ & 50,00 & Cukup \\
\hline $\mathbf{9}$ & $\mathrm{L}$ & 58,33 & Cukup \\
\hline $\mathbf{1 0}$ & $\mathrm{L}$ & 58,33 & Baik \\
\hline $\mathbf{1 1}$ & $\mathrm{P}$ & 66,67 & Sangat baik \\
\hline $\mathbf{1 2}$ & $\mathrm{L}$ & 83,33 & Sangat baik \\
\hline $\mathbf{1 3}$ & $\mathrm{L}$ & 100,00 & Sangat baik \\
\hline $\mathbf{1 4}$ & P & 100,00 & Sangat baik \\
\hline $\mathbf{1 5}$ & P & 91,67 & Sangat baik \\
\hline $\mathbf{1 6}$ & P & 100,00 & Sangat baik \\
\hline $\mathbf{1 7}$ & P & 91,67 & Sangat baik \\
\hline Rata-Rata Nilai & P & 100,00 & \\
\hline & & $\mathbf{8 1 , 3 7}$ & \\
\hline
\end{tabular}

Tabel 4. Data Hasil Penilaian Menulis Al-Quran Di SD Berbasis Islam 


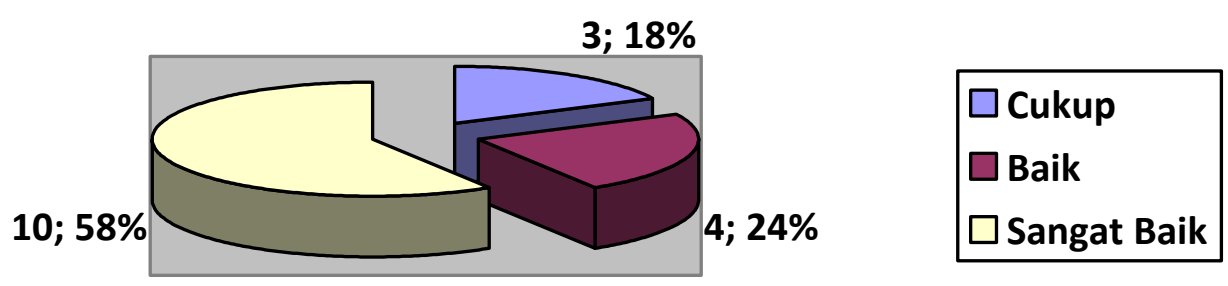

Diagram 2. Kriteria Kemampuan Menulis Al-Quran Siswa SD Berbasis Islam

Keterampilan menulis Al-Qur'an adalah catatan siswa dalam menulis hurufhuruf hijaiyah sehingga menjadi suatu rangkaian kalimat, ayat-ayat Al-Qur'an dengan tanda baca yang sesuai. Setiap bahasa mempunyai tatanan dalam pola kalmat yang berbeda dan unik, begitu juga dengan bahasa arab (Wulandari 2018). Bahasa arab memiliki tatanan yang kompleks dan sangat unik dan dinilai memiliki makna yang tinggi. Menurut Wulandari (2018) cara penulisan huruf-huruf AlQur'an atau huruf arab yaitu sebagai berikut:

a. Dimulai dari kanan ke kiri.

b. Menyambung huruf hijaiyyah, ada yang dapat disambung menyambung namun ada yang tidak dapat disambung menyambung.

c. Menguasai huruf dari segi letaknya dan bunyinya.

Berdasarkan penelitian yang telah dilakukan, diperoleh hasil yaitu untuk SD umum dapat dilihat pada diagram 1, 14 orang siswa dengan kriteria menulis AlQur'an sangat baik dengan persentase sebesar 82\%, 2 orang siswa dengan kriteria baik dengan persentase sebesar $12 \%$, dan 1 orang siswa mendapatkan kriteria cukup dengan persentase sebesar 6\%. Sehingga dapat dilihat pada tabel 3, diperoleh juga rata-rata nilai kemampuan menulis Al-Qur'an dari SD umum sebesar 90,17.

Sedangkan untuk SD berbasis islam dilihat pada diagram 2, 10 orang siswa dengan kriteria menulis Al-Qur'an sangat baik dengan persentase sebesar 58\%, 4 orang siswa mendapatkan kriteria baik dengan persentase sebesar 24\%, dan 3 orang siswa mendapatkan kriteria cukup dengan persentase sebesar $18 \%$. 
Sehingga dapat dilihat pada tabel 4 , diperoleh juga rata-rata nilai kemampuan menulis Al-Qur'an dari SD berbasis islam sebesar 81,37.

Terampil dalam menulis Al-Qur'an adalah salah satu tujuan dalam pembelajaran Al-Qur'an, di sekolah-sekolah terutama sekolah yang berbasis agama islam (Alwi 2018). Pembelajaran menulis Al-Qur'an memiliki tujuan agar siswa dapat menulis dengan baik dan tepat. Adapun beberapa indikator keterampilan menulis Al-Qur'an menurut (Alwi 2018), yaitu:

Ketepatan menulis huruf hijaiyyah. Tepat menulis huruf yang disambung dan yang tidak dapat disambung.

a. Kerapian dalam menulis ayat-ayat Al-Qur'an

b. Kelancaran dalam menulis Al-Qur'an

Sehingga penilaian pada penelitian ini didasarkan pada instrumen yang telah dibuat dan disajikan pada tabel 1 yaitu penilaian dari aspek tulisan huruf hijaiyyah, ketepatan tanda baca dan kerapihan tulisan. Skor tersebut diolah dengan pedoman penilaian tertentu dengan skor maksimal sebesar 12 poin, lalu hasil dari skor yang telah diolah menjadi nilai direpresentasikan kepada kriteria tertentu dimana rentang nilai 81-100 memiliki kriteria sangat baik, rentang nilai 61-80 memiliki kriteria baik, rentang nilai 41-60 memiliki kriteria cukup, rentang nilai 21-40 dengan kriteria kurang dan rentang nilai 20 ke bawah memiliki kriteria perlu bimbingan.

2. Perbedaan Kemampuan Menulis Al-Qur'an antara Siswa Laki-laki dengan Siswa Perempuan

\begin{tabular}{crc}
\hline Siswa Ke- & \multicolumn{1}{c}{ Nilai } & Kriteria Kemampuan Menulis Al-Quran \\
\hline $\mathbf{1}$ & 66,67 & Baik \\
\hline $\mathbf{3}$ & 91,67 & Sangat baik \\
\hline $\mathbf{4}$ & 100,00 & Sangat baik \\
\hline $\mathbf{7}$ & 91,67 & Sangat baik \\
\hline $\mathbf{1 1}$ & 75,00 & Baik \\
\hline $\mathbf{1 2}$ & 58,33 & Cukup \\
\hline $\mathbf{1 6}$ & 100,00 & Sangat baik \\
\hline Rata-rata nilai & 100,00 & Sangat baik \\
\hline
\end{tabular}

Tabel 5. Data Nilai Menulis Al-Qur'an Siswa Laki-laki SD Umum 
Endang Solihah, Salsabila Siti Nafisyah, Wita Puspita Dewi, Ani Nur Aeni

\begin{tabular}{crl}
\hline Siswa Ke- & Nilai & Kriteria Kemampuan Menulis Al-Quran \\
\hline $\mathbf{2}$ & 100,00 & Sangat baik \\
\hline $\mathbf{5}$ & 91,67 & Sangat baik \\
\hline $\mathbf{6}$ & 91,67 & Sangat baik \\
\hline $\mathbf{8}$ & 83,33 & Sangat baik \\
\hline $\mathbf{9}$ & 100,00 & Sangat baik \\
\hline $\mathbf{1 0}$ & 100,00 & Sangat baik \\
\hline $\mathbf{1 3}$ & 83,33 & Sangat baik \\
\hline $\mathbf{1 4}$ & 100,00 & Sangat baik \\
\hline $\mathbf{1 7}$ & 100,00 & Sangat baik \\
\hline Rata-Rata Nilai & $\mathbf{9 4 , 4 4}$ & \\
\hline
\end{tabular}

Tabel 6. Data Nilai Menulis Al-Qur'an Siswa Perempuan SD Umum

\begin{tabular}{crc}
\hline Siswa Ke- & Nilai & Kriteria Kemampuan Menulis Al-Quran \\
\hline $\mathbf{2}$ & 83,33 & Sangat baik \\
\hline $\mathbf{3}$ & 66,67 & Baik \\
\hline $\mathbf{4}$ & 66,67 & Baik \\
\hline $\mathbf{5}$ & 100,00 & Sangat baik \\
\hline $\mathbf{7}$ & 50,00 & Cukup \\
\hline $\mathbf{8}$ & 58,33 & Cukup \\
\hline $\mathbf{9}$ & 58,33 & Cukup \\
\hline $\mathbf{1 1}$ & 83,33 & Sangat baik \\
\hline $\mathbf{1 2}$ & 100,00 & Sangat baik \\
\hline Rata-Rata Nilai & $\mathbf{7 4 , 0 7}$ & \\
\hline
\end{tabular}

Tabel 7. Data Nilai Menulis Al-Qur'an Siswa Laki-laki SD Berbasis Islam

\begin{tabular}{crc}
\hline Siswa Ke- & \multicolumn{1}{c}{ Nilai } & Kriteria Kemampuan Menulis Al-Quran \\
\hline $\mathbf{1}$ & 100,00 & Sangat baik \\
\hline $\mathbf{6}$ & 66,67 & Baik \\
\hline $\mathbf{1 0}$ & 66,67 & Baik \\
\hline $\mathbf{1 3}$ & 100,00 & Sangat baik \\
\hline $\mathbf{1 4}$ & 91,67 & Sangat baik \\
\hline $\mathbf{1 5}$ & 100,00 & Sangat baik \\
\hline $\mathbf{1 6}$ & 91,67 & Sangat baik \\
\hline $\mathbf{1 7}$ & 100,00 & Sangat baik \\
\hline Rata-rata nilai & $\mathbf{8 9 , 5 8}$ & \\
\hline
\end{tabular}

Tabel 8. Data Nilai Menulis Al-Qur'an Siswa Perempuan SD Berbasis Islam 
Endang Solihah, Salsabila Siti Nafisyah, Wita Puspita Dewi, Ani Nur Aeni

\begin{tabular}{|c|c|c|}
\hline Siswa Ke- & Nilai & Kriteria Kemampuan Menulis Al-Quran \\
\hline \multicolumn{3}{|c|}{ Siswa Laki-laki SD Umum } \\
\hline 1 & 66,67 & Baik \\
\hline 3 & 91,67 & Sangat baik \\
\hline 4 & 100,00 & Sangat baik \\
\hline 7 & 91,67 & Sangat baik \\
\hline 11 & 75,00 & Baik \\
\hline 12 & 58,33 & Cukup \\
\hline 15 & 100,00 & Sangat baik \\
\hline 16 & 100,00 & Sangat baik \\
\hline \multicolumn{3}{|c|}{ Siswa Laki-laki SD Berbasis Islam } \\
\hline 2 & 83,33 & Sangat baik \\
\hline 3 & 66,67 & Baik \\
\hline 4 & 66,67 & Baik \\
\hline 5 & 100,00 & Sangat baik \\
\hline 7 & 50,00 & Cukup \\
\hline 8 & 58,33 & Cukup \\
\hline 9 & 58,33 & Cukup \\
\hline 11 & 83,33 & Sangat baik \\
\hline 12 & 100,00 & Sangat baik \\
\hline Rata-rata nilai & 74,56 & \\
\hline
\end{tabular}

Tabel 9. Data Nilai Menulis Al-Qur'an Siswa Laki-laki secara Keseluruhan

\begin{tabular}{|c|c|c|}
\hline Siswa Ke- & Nilai & Kriteria Kemampuan Menulis Al-Quran \\
\hline \multicolumn{3}{|c|}{ Siswa Perempuan SD Umum } \\
\hline 2 & 100,00 & Sangat baik \\
\hline 5 & 91,67 & Sangat baik \\
\hline 6 & 91,67 & Sangat baik \\
\hline 8 & 83,33 & Sangat baik \\
\hline 9 & 100,00 & Sangat baik \\
\hline 10 & 100,00 & Sangat baik \\
\hline 13 & 83,33 & Sangat baik \\
\hline 14 & 100,00 & Sangat baik \\
\hline 17 & 100,00 & Sangat baik \\
\hline \multicolumn{3}{|c|}{ Siswa Perempuan SD Berbasis Islam } \\
\hline 1 & 100,00 & Sangat baik \\
\hline 6 & 66,67 & Baik \\
\hline
\end{tabular}




\begin{tabular}{crl}
\hline $\mathbf{1 0}$ & 66,67 & Baik \\
\hline $\mathbf{1 3}$ & 100,00 & Sangat baik \\
\hline $\mathbf{1 4}$ & 91,67 & Sangat baik \\
\hline $\mathbf{1 5}$ & 100,00 & Sangat baik \\
\hline $\mathbf{1 6}$ & 91,67 & Sangat baik \\
\hline $\mathbf{1 7}$ & 100,00 & Sangat baik \\
\hline Rata-rata nilai & 92,16 &
\end{tabular}

Tabel 10. Data Nilai Menulis Al-Qur'an Siswa Perempuan secara Keseluruhan

Dari hasil temuan yang ditemukan peneliti mengenai perbedaan kemampuan menulis Al-Qur'an antara antara siswa laki-laki dengan siswa perempuan, dapat dilihat pada tabel 5 \& 6 bahwasannya di SD umum untuk siswa laki-laki mendapat rata-rata nilai sebesar 85,42 dan siswa perempuan mendapat rata-rata nilai sebesar 94,44. Dari kedua rata-rata nilai tersebut, dapat disimpulkan bahwa kemampuan menulis Al-Qur'an di SD umum lebih unggul siswa perempuan.

Sedangkan, di SD berbasis islam dapat dilihat pada tabel $7 \& 8$, untuk siswa laki-laki mendapat rata-rata nilai sebesar 74,07 dan siswa perempuan mendapat rata-rata nilai sebesar 89,58. Dari kedua rata-rata nilai tersebut, dapat disimpulkan bahwa kemampuan menulis Al-Qur'an di SD berbasis Islam lebih unggul siswa perempuan.

Selanjutnya seperti yang terlihat pada tabel $9 \& 10$, peneliti membandingkan nilai secara keseluruhan antara siswa laki-laki baik di SD umum dan SD berbasis islam dengan siswa perempuan di SD umum dan SD berbasis Islam. Dari hasil membandingkan secara keseluruhan tersebut, didapat hasil rata-rata nilai menulis Al-Qur'an siswa laki-laki sebesar 74,56 dan rata-rata nilai menulis Al-Qur'an siswa perempuan sebesar 92,16. Setelah dibandingkan secara keseluruhan pun tetap saja siswa perempuan lebih unggul dari siswa laki-laki dalam hal kemampuan menulis Al-Qur'an.

\section{Faktor yang mempengaruhi kemampuan menulis Al-Qur'an}

Kemampuan siswa dalam menulis Al-Qur'an dipengaruhi oleh beberapa faktor yaitu internal dan eksternal (Nasution 2016), yaitu:

a. Faktor internal, faktor dari dalam diri siswa yang meliputi keadaan jasmani serta rohani siswa. Hal ini meliputi:

1) Aspek fisiologis, yaitu aspek jasmani atau kebugaran dari tubuh siswa tersebut.

2) Aspek psikologis, seperti tingkat kecerdasan, sikap, bakat, minat, dan motivasi siswa.

b. Faktor eksternal, yaitu faktor dari luar atau lingkungan siswa, meliputi: 
1) Keluarga, keluarga atau orang tua adalah guru pertama bagi anak-anaknya, jika dalam keluarga anak sudah diberikan pendidikan dengan baik maka ia akan lebih unggul.

2) Masyarakat, lingkungan masyarakat adalah salah satu faktor terbesar yang mempengaruhi kemajuan pendidikan Al-Qur'an karena tidak terlepas dari adat dan istiadat yang memajukan pendidikan Al-Qur'an, misalnya adanya pengajian rutin.

Berdasarkan hasil penelitian diperoleh rata-rata nilai kemampuan menulis Al-Qur'an untuk SD umum sebesar 90,17, sedangkan rata-rata nilai kemampuan menulis Al-Qur'an untuk SD berbasis Islam sebesar 81,37. Ada selisih nilai sebesar 8,80. Dengan perbedaan nilai yang tidak terpaut jauh, perbedaan kemampuan menulis Al-Qur'an antara siswa SD umum dan siswa SD berbasis Islam tidak signifikan. Artinya terdapat perbedaan kemampuan menulis Al-Qur'an antara siswa SD umum dan siswa SD berbasis Islam. Perbedaan kemampuan tersebut dipengaruhi oleh faktor internal dan eksternal seperti yang tercantum di atas atau faktor lainnya seperti akibat dari perkembangan teknologi, penggunaan alat canggih, atau proses digitalisasi sehingga sehingga menurunkan motivasi siswa dalam belajar menulis Al-Qur'an.

\section{SIMPULAN}

Berdasarkan hasil penelitian dapat disimpulkan bahwa: 1) Kemampuan menulis Al-Qur'an siswa SD umum lebih unggul siswa SD berbasis Islam, 2) Terdapat perbedaan kemampuan menulis Al-Qur'an antara siswa SD umum dengan siswa SD berbasis Islam dan perbedaan tersebut terlihat dari perbedaan nilai rata-rata terdapat selisih sebesar 8,80, 3) Jenis sekolah tidak berpengaruh terhadap kemampuan menulis Al-Qur'an siswa, dan 4) Gender mempengaruhi kemampuan menulis Al-Qur'an karena terdapat perbedaan hasil dimana siswa perempuan lebih unggul daripada siswa laki-laki. Peneliti menyarankan untuk peneliti selanjutnya yang akan mengkaji topik yang sama disarankan untuk lebih memperdalam faktor-faktor yang mempengaruhi kemampuan menulis Al-Qur'an dan untuk partisipan alangkah lebih baiknya mengambil sampel dari satu kelas di sekolah yang sama baik SD umum dan SD berbasis Islam.

\section{DAFTAR RUJUKAN}

Aeni, A. N. (2017). Hifdz Al-Quran: Program Unggulan Full Day School Dalam Membentuk Karakter Qurani Siswa SD. TARBAWY: Indonesian Journal of Islamic Education, 4(1), 32-43. 
Alwi, A. M. (2018). Implementasi program baca tulis Al-Qur'an terhadap kemampuan membaca dan kemampuan menulis Al-Qur'an peserta didik kelas VIII MTs As'adiyah No. 3 Atapange Kabupaten Wajo. IAIN Parepare.

Aminah, S. (2019). Implementasi Model Pembelajaran Cooperative Integrated Reading and Composition dalam Meningkatkan Kemampuan Membaca dan Menulis al Qur'an Siswa di SDN Tanah Kali Kedinding V Surabaya. ELBANAT: Jurnal Pemikiran dan Pendidikan Islam, 9(2), 177-196.

Nasution, S. (2016). Faktor-faktor yang mempengaruhi kemampuan baca tulis AlQur'an siswa SMPN 2 Batangtoru Kecamatan Batangtoru Kebupaten Tapanuli Selatan. IAIN Padangsidimpuan.

Sugiyono. (2019). Metode Penelitian Kualitatif, Kuantitatif, dan $R \&$ D. Bandung: Alfabeta.

Supriyadi, T., Julia, J., Iswara, P. D., \& Aeni, A. N. (2019). Eradicating Al-Qur'an Illiteracy of Prospective Primary School Teachers . In Elementary School Forum (Mimbar Sekolah Dasar), 6(2), 219-238.

Wulandari, W. I. (2018). Peningkatan keterampilan menulis huruf al-Quran (Surat Al-Maun, Al-Kafirun, At-Takasur) melalui practice rehearsal pairs di kelas $V$ SD Al-Islamiyah Tanggulangin Sidoarjo. UIN Sunan Ampel. 